\title{
Factors associated with congenital anomalies in Addis Ababa and the Amhara Region, Ethiopia: a case-control study
}

\author{
Molla Taye ${ }^{1 *}$, Mekbeb Afework ${ }^{2}$, Wondwossen Fantaye $^{3}$, Ermias Diro ${ }^{4}$ and Alemayehu Worku ${ }^{5}$
}

\begin{abstract}
Background: The early stage of embryo development is extremely vulnerable to various teratogenic factors, leading to congenital anomalies. In Ethiopia, a significant number of babies are born with congenital anomalies, but the risk factors for the anomalies have never been studied. Understanding the specific risk factors for congenital anomalies is very essential to provide health education that aims at creating awareness and establishing preventive strategic plan/s. The main objective of this study was to assess the risk factors associated with congenital anomalies in Addis Ababa and the Amhara Region, Ethiopia.

Methods: A case-control study was conducted from January 1- June 30, 2015. The participants were recruited at the purposively selected hospitals in Addis Ababa and the Amhara Region. A total of 207 cases and 207 controls were included in the study. Cases were neonates, infants, and children 0-11 months of age with external and internal major congenital anomalies diagnosed by pediatricians. Controls were neonates, infants, and children 0-11 months of age without external and internal anomalies. Data on sociodemographic characteristics, exposure to risk factors, and reproductive history were collected by face to face interviews with children's mothers/caregivers using a structured questionnaire. Binary logistic regression was employed to explore risk factors associated with the occurrence of the problems.
\end{abstract}

Results: About $87.4 \%$ of the children were below 6 months, and $12.6 \%$ were between 6 and 11 months. The majority (59.9\%) of the children were male, with the M: F sex ratio of 1.49. The mean age of the mothers was 26 years (16-45 years). Unidentified medication use during early pregnancy (AOR $=4.595 ; 95 \% \mathrm{Cl}: 1.868-11.301, P$-value $=0.001$ ), maternal alcohol drinking $(A O R=2.394 ; 95 \% \mathrm{Cl}: 1.212-4.726, P$-value $=0.012)$, and exposure to chemicals $(A O R=9.964$; $95 \% \mathrm{Cl}=1.238-80.193, P$-value $=0.031)$ were significantly associated with the occurrence of congenital anomalies. Iron folate use (AOR $=0.051 ; 95 \% \mathrm{Cl}: 0.010-0.260, P$-value $=<0.001$ ) before and during early pregnancy had a protective effect on congenital anomaly.

Conclusion: Unidentified medication use, alcohol drinking during early pregnancy, and exposure to chemicals had a significant association with the occurrence of congenital anomalies, whereas iron folate use before and during early pregnancy had a protective effect from congenital anomalies.

Keywords: Congenital anomaly, Case-control, Teratogen, Risk/Associated factors

\footnotetext{
* Correspondence: mollataye2@gmail.com

${ }^{1}$ Department of Anatomy, School of Medicine, College of Medicine and

Health Sciences, the University of Gondar, Gondar, Ethiopia

Full list of author information is available at the end of the article
} 


\section{Background}

The early stages of embryo development are a critical period which may mark vulnerability to disruption by teratogenic agents that lead to congenital anomaly [1-3]. Congenital anomaly (CA) is defined as a structural or functional defect that may be detected during pregnancy or be visible at birth or later in life. CAs are the major cause of new born/infant morbidity, mortality, and disability in addition to adding to the burden of the health care system [4]. It is estimated that about $20-30 \%$ of infant deaths occur due to CAs [5]; severe CAs occur in $3 \%$ of live $[6,7]$, and $20 \%$ of still births [8], and 7.9 million children are born with serious CAs, accounting for $6 \%$ of all births globally [9].

According to literature, genetic and environmental factors play a major role in causing CAs during the first trimester [10]. Approximately, 7.6 million children are born with CAs worldwide due to genetic factors [11]. Although there is a better understanding of the etiology of CA in the literature, the causes of most of the CAs are still unknown. However, they are believed to be caused by several etiologic factors $[12,13]$.

The occurrence of certain risk factors, such as maternal chronic diseases, like diabetes, family history, and viral infections during early pregnancy increase the risk of having a baby with CAs [14-17]. Furthermore, risk factors linked to the occurrence of CAs include unidentified medication/illicit/prescribed drug/s use, alcohol consumption, smoking cigarettes, exposure to radiation, chemical agents, parental age, parental occupation, nutritional deficiencies, and chromosomal mutations as well as socio-economic factors [7, 14, 15, 18-20]. Hence, exposure to all of these factors can influence the organogenesis processes of the embryo [7, 12].

Moreover, some studies showed that maternal use of folic acid and multivitamins containing folic acid around conception and the first 3 months of pregnancy have a protective effect against certain types of CAs [21, 22].

In general, the prevalence of CAs varies with race, ethnicity, and geographical regions across the world [7, 11, 16, 23, 24]. In Ethiopia, a significant number of babies are born with CAs, but the causes of these CAs have never been studied. In fact, whether the causes are environmental or genetic factors or interactions between environmental and genetic factors are not known. In addition, there are no preventive strategic plans to reduce or control the occurrence of these problems. It is obvious that children born with major CA are prone to die or even if they survive, they may confront a longterm morbidity and disability and may also undergo repeated surgical interventions. Evidence based information about specific risk factors for CAs are very essential to provide health education to communities, especially to females in the reproductive age. This could not only help to create awareness so as to reduce the occurrence of anomalies but also assists policy makers/responsible bodies to develop preventive strategic plans.

The main objective of this study was to assess the risk factors for CAs in Addis Ababa and the Amhara Region. The results are believed to provide information for public health actions and to create awareness about CAs and their etiologic factors. They may also be used as baseline for further investigations.

\section{Methods \\ Study sites}

The study was carried out in Addis Ababa and the Amhara region, Ethiopia.

Addis Ababa, the capital of Ethiopia, has 10 sub-cities with an estimated total population of 3,273,001(47.4\% male, $52.6 \%$ female). The population of Addis is diverse by ethnicity. The majority of the people are Christians, followed by Muslims and some followers of other religions [25]. The city is subject to population increase through continuous migrations [25]. All of the hospitals in the city provide inpatient, outpatient, and delivery services, except Cure Ethiopia International Children's Hospital, which does not provide delivery services.

The Amhara Region, the second largest northwest region of the country has a population of 20,399,004 (50. $1 \%$ male, $49.9 \%$ female). The majority of the people live in rural areas and the minority in large and small towns. Most of the Amhara people are Christians, with a good number of Muslims and some followers of other faiths [25]. All of the hospitals in the regional state provide various inpatient and outpatient services including delivery.

\section{Selection of study hospitals}

Five public hospitals in Addis Ababa and three in the Amhara Region were purposively selected for this study on the basis of case load. All of the hospitals are referral with high patient flow and various specialized departments or units, which provide various services to neonates, infants, children, and adults.

\section{Study design and sample size}

A case-control design was used to investigate exposure status to risk factors for CAs in the case and control children.

A sample of 414 children (207 cases, 207 controls) was recruited for this study. The sample size was calculated by using a ratio of $1: 1$, power of $90 \%$, a $5 \%$ significance level and $38.81 \%$ of likelihood of an event in controls (i.e. exposure in controls) [17], and assuming the Odds ratio to be 2 . The study children were matched by age. Cases were neonates, infants, and children 0-11 months of age with external and internal major CAs. Major CAs are defined as anomalies that have partial or complete organ/ organ system absence/defects, resulting in functional, 
health, and cosmetic effects, which require surgical repair and rehabilitations [4]. The cases were selected from live births at the study hospitals, neonate units and under five clinics. The type of CAs were classified as major by using WHO/CDC/ICBDSR manual 2014 [4]. Based on WHO/ CDC/ICBDSR classification method, the cases with neural tube, orofacial region, musculoskeletal system and genitourinary system defects and less than 12 months of age were purposively selected and included in the study. Children aged 12 months and above and had major and minor CA were excluded. All cases had isolated CAs except one child who had multiple anomalies. The diagnoses of the cases were confirmed through physical examinations and echocardiography (i.e. for cases with heart defects) by pediatricians. The cases were selected purposively. The controls were neonates, infants, and children 0-11 months of age without external and internal CAs. The controls were randomly selected in the same hospitals where children with CAs were identified. All children aged 011 months constituted the source population.

\section{Data collection method}

The data were collected by a face to face interview of the children's mothers/caregivers by using a structured questionnaire and checklists. The questionnaire prepared in English and translated to Amharic was pretested at other hospitals and amended according to the results. Data were collected on residence, sociodemographic characteristics, reproductive/pregnancy history and adverse outcomes, family history of CAs, socioeconomic status, parental ethnicity, parental occupation, maternal educational level, maternal nutritional status/ history, parental exposures to risk factors and/or teratogenic agents, such as radiation, chemicals, pesticides, etc. for CAs, maternal illness/disease, medication/illicit drug use, substance abuse (alcohol consumption, smoking), blood relationships among parents, antenatal care visits, folic acid and multivitamin use, and birth order of children. The data were gathered at delivery rooms/ wards, neonatal units, and under five clinics. Prior to data collection, data collectors (nurses, midwifes) were trained for 2 days. The data were collected from January 1- June 30, 2015.

\section{Data management and analysis}

Data were checked on daily basis by collectors and further overseen by the principal investigator and supervisors for completeness and correctness during collection periods. It was also rechecked during data entry. The data were coded and entered into Epi-Info version 3.5.1 and then transferred to SPSS version 21 for analysis. Data cleaning, error checking, and analysis were conducted by using SPSS version 21. Data were calculated by using frequency, cross tabulation, and binary logistic regression. Significance level was considered at less than $0.05 p$-value. Crude Odds ratio and confidence level were calculated. After the crude Odds ratios were identified, adjusted Odds ratios were computed to assess risk factors associated with the occurrence of CAs by using backward stepwise logistic regression. Exposure variables with $P$-value $\leq 0.2$ in the crude Odds ratio were entered into the multivariable logistic regression model to observe their relationships and CAs (i.e. to observe associated variables with CAs in the adjusted Odds ratio). The characteristics of cases and controls were explained in percentages and numbers. The crude and adjusted Odds ratios, confidence intervals, $p$-values and the overall findings are presented in the result section in the form of texts and tables.

\section{Ethical clearance}

Ethical clearance was obtained from Addis Ababa University, College of Health Sciences Institutional Review Board, the National Research Ethics Review Committee, Addis Ababa City Administration Health Bureau Ethical Clearance Committee, and the Amhara National Regional State Health Bureau Regional Health Research Laboratory Center. Supportive letters were written to all zonal health departments and study hospitals by the health bureaus. Ethical and supportive letters were submitted to all hospital administrators. The purpose of the study was explained to the participant children's mothers/caregivers. Data collection began after permissions were obtained from hospital managers/medical directors and after a written consent was obtained from children's mothers/caretakers. Data collected from the participants were kept in secured and locked cabinets in order to maintain confidentiality.

\section{Results}

Socio-demographic characteristics of the study participants The sample consisted of 414 (207 cases, 207 controls) children. The age of children ranged from 1 day to 11 months. About $87.4 \%$ of the children were below 6 months and 12 . $6 \%$ between 6 and 11 months. The majority (59.9\%) of the children were male and $40.1 \%$ female with a sex ratio of 1 . 49 , respectively. The mean age of the children's mothers was 26 years (range 16-45). Among the participants, 63.3\% were urban and $36.7 \%$ rural dwellers. In terms of income, $47.8 \%$ had middle and $37.2 \%$ low economic status as stated by the mothers/respondents. The majority $(93.5 \%)$ of the children's mothers were married; about $37.4 \%$ had no formal education; $31.9 \%$ had primary education, and 30.7\% secondary and higher level of education. By religious affiliation, 72.2, 27.3, and $0.5 \%$ of the parents were Christian, Muslim, and others, respectively. Among the mothers, 53\% were housewives, $17.9 \%$ government, private, or selfemployed, $14.3 \%$ farmers, and $14 \%$ jobless. Similarly, 49.3, 38.9 , and $11.8 \%$ of the children's fathers were employees, 
farmers, and jobless, respectively. The major (62.1\%) ethnic group in this study were Amhara, 23.2\% Oromo, 5.6\% Guragie, 3.6\% Tigre, and 3.6\% Seltie. The other sociodemographic characteristics of the participants are shown in Table 1.

About 12 (5.8\%) and 13 (6.3\%) of mothers whose children had and had no CAs, respectively, were in the 15-19 years of age group. Besides, 49 (23\%) and 68 (32.9\%) of mothers whose children were exposed and not exposed to CAs, respectively, were 20-24 years of age. Similarly, $69(33.3 \%)$ and 68 (32.9\%) of the mothers who had children with and without CAs, respectively, were in the 25-29 years of age group, whereas $49(23.7 \%)$ and $31(15 \%)$ mothers who had and free children, respectively, were in the 30-34 years of age group. Likewise, 28 (13.5\%) and $27(13 \%)$ of the mothers who had affected and non-affected children, respectively, were 35-39 years of age.

About $99.5 \%$ of the CAs identified were isolated/single, while $1(0.5 \%)$ was multiple. The frequency of CAs by organ/organ system is shown in Table 2 .

Reproductive, obstetric, and offspring background/history As far as the birth order of children was concerned, 32.9, 19.8 , and $47.3 \%$ were first, second, third and above (3+) children to their families, respectively. Among the controls, about 48.3, 22.7, and $29 \%$ were first, second, third and above (3+) children, respectively, to their parents. About $16.4 \%$ of mothers whose children had CAs and 9 . $2 \%$ of the mothers who had children without CAs, had no antenatal care (ANC) visits. The total number of pregnancy history, preterm, miscarriage, stillbirth, gravidity, gestational age at first ANC, number of live births, and neonate/infant/child deaths are presented in Table 3.

\section{Risk factors associated with congenital anomalies}

There were maternal/medical illnesses (i.e. infections or chronic diseases such as diseases with fever, chronic disorders) in $24(11.6 \%)$ of the mothers who had children with CAs and 13 (6.3\%) of mothers whose children were not affected with CAs. Passive smokers were observed in $37(17.9 \%)$ and 28 (13.5\%) of mothers who had children with and without CAs, respectively. Among the participants, unidentified medication use in early pregnancy by mothers whose children had and had no CAs were 16.9 and $3.9 \%$, respectively. Contraceptive (both pill and injection) use around conception was $11.6 \%$ in the mothers who had children with CAs and $2.4 \%$ in the mothers who had no children with CAs. In addition, anemia was observed in $55(26.6 \%)$ of the affected children's mothers and 37 (17.9\%) of mothers whose children had no CAs (Table 4).

Blood relationships among parents were reported in 4 . $8 \%$ of children's the exposed mothers and $1.0 \%$ of not exposed children's mothers. Family history of CA as seen in the children was also reported in $4.3 \%$ of the affected children's parents and $1.4 \%$ of the parents whose children had no CAs. Exposure to chemicals among mothers who had children with and without CAs was 6 . 3 and $0.5 \%$, respectively. On the other hand, two $(0.97 \%)$ of mothers whose children had CAs used fertility enhancing drugs. Again, one $(0.5 \%)$ of the affected child mother had diabetes during pregnancy. On the contrary, mothers who had children without CAs reported no use of fertility enhancing drugs around conception and had no diabetes during and before pregnancy. In addition, none of the affected children's mothers took multivitamins before they got pregnant, while one $(0.5 \%)$ of the mother who had child without CA used multivitamin before pregnancy. Moreover, about 25 (12.1\%) of mothers whose children had CAs and 17 (8.2\%) of the mothers who had children without CAs, had no food shortage before and during pregnancy (Table 4). However, the above-mentioned factors were not statistically significant in the multivariable analysis, the adjusted Odds Ratio. In addition, maternal age, parental ethnicity, mothers educational level, parental occupation (Table 1) and parity, birth order, preterm, still birth, and miscarriage (Table 3) were not statistically significant in the crude and adjusted Odds Ratio analysis.

Thirteen variables were entered into the COR analysis. Of these, unidentified medication used during the first 3 months of gestation $(\mathrm{COR}=5.062$; 95\% CI: $2.286-11$. 206, $P$-value $=<0.001)$, alcohol consumption during early/throughout pregnancy $(\mathrm{COR}=3.256 ; 95 \% \mathrm{CI}: 1$. $823-5.816, P$-value $=<0.001)$, anemia during early pregnancy $(\mathrm{COR}=1.663 ; 95 \% \mathrm{CI}: 1.038-2.662, p$-value $=0$. 034), contraceptive use around conception $(\mathrm{COR}=5$. 298; 95\% CI: $1.980-14.175, P$-value $=0.001)$, and chemical exposure during early pregnancy $(\mathrm{COR}=13.804$; 95\% CI; 1.789-106.522, $P$-value $=0.012$ ), and blood relation among parents $(\mathrm{COR}=5.203$; 95\% CI:1.126-24.046, $P$-value $=0.035)$ were associated with CAs in the crude Odds ratio analysis. On the other hand, folic acid/iron folate $(\mathrm{COR}=0.082 ; 95 \%$ CI: 0.019-.354, $P$-value $=0.001)$ and vegetable servings/use during early pregnancy (COR $=0.536$; $95 \%$ CI: $0.344-0.835, P$-value $=0.006)$ was protective against the occurrence of CAs (Table 4). However, vegetable serving was not associated with the occurrence of CAs in the adjusted Odds ratio analysis.

Twelve variables (alcohol drinking, anemia, iron folate/ folic acid, unidentified medication, contraceptive, exposure to chemicals, vegetable serving, blood relationship between child parents, exposure to radiation, maternal illness, family history, and food shortage during early pregnancy) whose value ended up with 0.2 and below in the crude Odds ratio were entered into the multivariable logistic regression model to observe exposure variables 
Table 1 The socio-demographic characteristics of the study participants, Addis Ababa and the Amhara Region, Ethiopia, 2016

\begin{tabular}{|c|c|c|c|c|c|c|c|}
\hline \multirow[t]{2}{*}{ Characteristics } & & \multicolumn{2}{|c|}{ Cases $(n=207)$} & \multicolumn{2}{|c|}{ Controls $(n=207)$} & \multicolumn{2}{|c|}{ Total $(n=414)$} \\
\hline & & Frequency & $\%$ & Frequency & $\%$ & Frequency & $\%$ \\
\hline \multirow[t]{2}{*}{ Study Site } & Addis Ababa & 106 & 51.2 & 107 & 51.7 & 213 & 51.4 \\
\hline & Amhara Region & 101 & 48.8 & 100 & 48.3 & 201 & 48.6 \\
\hline \multirow[t]{2}{*}{ Infant/Child Age } & Below 6 months & 181 & 87.4 & 181 & 87.4 & 362 & 87.4 \\
\hline & 6-11 months & 26 & 12.6 & 26 & 12.6 & 52 & 12.6 \\
\hline \multirow[t]{2}{*}{ Infant/Child Sex } & Male & 123 & 59.4 & 125 & 60.4 & 248 & 59.9 \\
\hline & Female & 84 & 40.6 & 82 & 39.6 & 166 & 40.1 \\
\hline \multirow[t]{3}{*}{ Child Mother Age } & $<20$ years & 11 & 5.3 & 11 & 5.3 & 22 & 5.3 \\
\hline & 20-34 years & 167 & 80.7 & 169 & 81.6 & 336 & 81.2 \\
\hline & $>34$ years & 29 & 14.0 & 27 & 13.0 & 56 & 13.5 \\
\hline \multirow[t]{2}{*}{ Child Mother Marital status } & Married & 190 & 91.8 & 197 & 95.2 & 387 & 93.5 \\
\hline & Never married & 17 & 8.2 & 10 & 4.8 & 27 & 6.5 \\
\hline \multirow[t]{3}{*}{ Religion } & Christian & 139 & 67.1 & 160 & 77.3 & 299 & 72.2 \\
\hline & Muslim & 66 & 31.9 & 47 & 22.7 & 113 & 27.3 \\
\hline & Other & 2 & 1.0 & 0 & 0 & 2 & 0.5 \\
\hline \multirow[t]{3}{*}{ Child Mother Education } & No education & 101 & 48.8 & 54 & 26.1 & 155 & 37.4 \\
\hline & Primary & 59 & 28.5 & 73 & 35.3 & 132 & 31.9 \\
\hline & Secondary and higher & 47 & 22.7 & 80 & 38.6 & 127 & 30.7 \\
\hline \multirow[t]{2}{*}{ Monthly income } & Regular & 84 & 40.6 & 74 & 35.7 & 158 & 38.2 \\
\hline & Irregular & 123 & 59.4 & 133 & 64.3 & 256 & 61.8 \\
\hline \multirow[t]{4}{*}{ Child Mother Ethnicity } & Oromo & 63 & 30.4 & 33 & 15.9 & 96 & 23.2 \\
\hline & Amhara & 122 & 58.9 & 135 & 65.2 & 257 & 62.1 \\
\hline & Guragie & 7 & 3.4 & 17 & 8.2 & 24 & 5.8 \\
\hline & Others $^{\mathrm{a}}$ & 15 & 7.3 & 22 & 10.6 & 37 & 8.7 \\
\hline \multirow[t]{4}{*}{ Child Mother Occupation } & House wife & 122 & 58.9 & 101 & 48.8 & 223 & 53.9 \\
\hline & Employed & 28 & 13.5 & 46 & 22.2 & 74 & 17.9 \\
\hline & Farmer/Agriculture & 32 & 15.5 & 27 & 13.0 & 59 & 14.3 \\
\hline & No job/unemployed & 25 & 12.1 & 33 & 15.9 & 58 & 14.0 \\
\hline \multirow[t]{2}{*}{ Residence } & Urban & 97 & 46.9 & 165 & 79.7 & 262 & 63.3 \\
\hline & Rural & 110 & 53.1 & 42 & 20.3 & 152 & 36.7 \\
\hline \multirow[t]{3}{*}{ Economic Status } & Low & 89 & 43.0 & 65 & 31.4 & 154 & 37.2 \\
\hline & Middle & 100 & 48.3 & 98 & 47.3 & 198 & 47.8 \\
\hline & higher & 18 & 8.7 & 44 & 21.3 & 62 & 15.0 \\
\hline \multirow[t]{4}{*}{ Child Father Ethnicity } & Oromo & 63 & 30.4 & 33 & 15.9 & 96 & 23.2 \\
\hline & Amhara & 116 & 56 & 133 & 64.3 & 249 & 60.1 \\
\hline & Guragie & 8 & 3.9 & 15 & 7.2 & 23 & 5.6 \\
\hline & Others $^{\mathrm{a}}$ & 20 & 9.6 & 26 & 12.6 & 46 & 10.9 \\
\hline \multirow[t]{3}{*}{ Child Father Occupation } & Employed & 72 & 34.8 & 132 & 63.8 & 204 & 49.3 \\
\hline & Farmer/Agriculture & 107 & 51.7 & 54 & 26.1 & 161 & 38.9 \\
\hline & No job/unemployed & 28 & 13.5 & 21 & 10.1 & 49 & 11.8 \\
\hline \multirow[t]{4}{*}{ Region originated } & Amhara & 106 & 51.2 & 101 & 48.8 & 207 & 50.0 \\
\hline & Oromia & 45 & 21.7 & 18 & 8.7 & 63 & 15.2 \\
\hline & Addis Ababa & 35 & 16.9 & 80 & 38.6 & 115 & 27.8 \\
\hline & Other regions ${ }^{b}$ & 21 & 10.3 & 8 & 3.9 & 29 & 7.0 \\
\hline
\end{tabular}


Table 2 Frequency of congenital anomalies by organ/organ system among the study subjects, Addis Ababa and the Amhara Region, Ethiopia, 2016

\begin{tabular}{lll}
\hline Type of Congenital Anomalies & frequency & $\%$ \\
\hline $\begin{array}{l}\text { Neural Tube Defects (Spina bifida with and } \\
\text { without hydrocephaly, clubfoot; } \\
\text { encephalocele (occipital, frontal, and nasal)) }\end{array}$ & 124 & 30 \\
$\begin{array}{l}\text { Orofacial Clefts (cleft lip, cleft lip and palate, } \\
\text { and cleft palate) }\end{array}$ & 54 & 13 \\
$\begin{array}{l}\text { Masculoskeletal Defects (reduction defects } \\
\text { of tibia, femur, ulna, and radial bones, talipes }\end{array}$ & 20 & 4.8 \\
$\begin{array}{l}\text { equinovarus, tracheoesophageal fistula, } \\
\text { gastroschisis, and amelia of upper limb) }\end{array}$ & & \\
$\begin{array}{l}\text { Heart Defects (ventricular septal defects) } \\
\text { Genitourinary Anomalies (hypospadias with } \\
\text { sub-coronal and penile) }\end{array}$ & 5 & 1.2 \\
Bladder extrusion with cleft lip and palate & 1 & 0.7 \\
No Congenital Anomalies/Controls & 207 & 0.2 \\
Total & 414 & 50 \\
\hline
\end{tabular}

associated with CAs. As indicated in Table 4, unidentified medication use $(\mathrm{AOR}=4.595 ;$ 95\% CI: 1868-11.301, $P$-value $=0.001)$, maternal alcohol drinking in early pregnancy $(\mathrm{AOR}=2.394 ; 95 \% \mathrm{CI}: 1.212-4.726, P$-value $=0.012)$ , and exposure to chemicals during early pregnancy (AOR $=9.964 ; \quad 95 \%$ CI: $1.238-80.193, \quad P$-value $=0.031$ ) were significantly associated with the occurrence of CAs. On the contrary, iron folate/folic acid supplementation (use) before and during early pregnancy (AOR $=0.051$; 95\% CI: $0.010-0.260, P$-value $=<0.001)$ had a protective effect against CA.

\section{Discussion}

According to our findings, unidentified medication use, alcohol consumption during early pregnancy or throughout pregnancy, and exposure to chemicals during early pregnancy had significant associations with the occurrence of CAs in this study, whereas iron folate supplementation before and during early pregnancy showed a protective effect against CA.

Like our study, scientific literature reports that drug usage during pregnancy is associated with CAs [26-31]. In Ethiopia, drugs are being sold by private drug venders, stores, clinics, and some shops with and without prescriptions. This indicates that mothers are likely to use medications/over-the counter drugs during their early pregnancy. Therefore, responsible bodies should control over-the-counter.

The association of alcohol drinking during and before early pregnancy and CA was also reported by Grewal et al., [32], Zhang et al., [33], and O'Leary et al., [34, 35]. In the liver, alcohol is metabolized into acetaldehyde, a toxic chemical/substance. To convert this toxic substance into a non-toxic and usable chemical, enzyme acetaldehyde dehydrogenases that secreted converts the acetaldehyde into acetic acid, which is useable by the body. However, when the unconverted acetaldehyde accumulates in the body, it causes irritation of the cells and tissues and then damages the cells and tissues, leading to metabolism and cellular growth abnormalities [36]. Moreover, alcohol is capable of crossing the placenta membrane and being carried to all developing cells and tissues of the embryo and fetus, and as a result causes damages to the developing tissues and cells and subsequently leads to a structural abnormality. Furthermore, alcohol drinking during pregnancy results in a serious consequences which manifest with recognized characteristics of physical and mental abnormal features after a baby is born [36-44].

In Ethiopia, alcohol is consumed by the community $[45,46]$, particularly locally made alcoholic beverages known as "areki" and "tella" in Amharic are consumed by both men and women in rural communities, especially among Christians, more specifically Orthodox Christians, across the country, whereas some urban dwellers, including women drink beer and other alcoholic drinks. In this study, women who consumed alcohol daily and women who took alcohol to an increasing degree had children with CAs. Therefore, health education is essential for the community, particularly women in the 15-49 years of age group.

In the present study, exposure to chemicals had a significant association with CAs. Likewise, exposure to chemicals has been reported as having a significant association with the occurrence of CAs [47-51].

In this study, mothers of cases who reported maternal/ medical illnesses during early pregnancy had higher odds of babies with CAs compared to mothers of controls. Similarly, maternal diseases or medical illnesses, such as syphilis, Rubella, measles, other viral infections, [52-56] and chronic diseases were reported by several researchers as known causes of CAs [14, 18, 52-59].

Many studies reported that iron folate/folic acid supplementation in the early pregnancy and before protected or reduced the occurrence of certain CAs. For example, neural defects can be reduced if a pregnant woman appropriately takes the recommended dose of iron folate/folic acid. Women who take iron folate/folic acid are less likely to have babies with CA compared to those who do not take folic acid during and before early pregnancy [14, 60-68]. Folic acid together with vitamin B12 plays a vital role in the synthesis of nucleic acid, lipids, and proteins, required for cell division. Iron folate/folic acid also has a role in amino acids metabolisms that are needed for DNA and RNA synthesis and plays an important role as an antioxidant agent. Therefore, it is essential to make it available to all pregnant women. 
Table 3 Reproductive history of the study participants/children's mothers, Addis Ababa and the Amhara Region, Ethiopia, 2016

\begin{tabular}{|c|c|c|c|c|c|c|c|}
\hline \multirow[t]{2}{*}{ Characteristics } & & \multicolumn{2}{|l|}{ Cases } & \multicolumn{2}{|l|}{ Controls } & \multicolumn{2}{|l|}{ Total } \\
\hline & & $(n=207)$ & $\%$ & $(n=207)$ & $\%$ & $(n=414)$ & $\%$ \\
\hline \multirow[t]{3}{*}{ Birth order } & First & 68 & 32.9 & 100 & 48.3 & 168 & 40.6 \\
\hline & Second & 41 & 19.8 & 47 & 22.7 & 88 & 21.3 \\
\hline & Third and above & 98 & 47.3 & 60 & 29.0 & 158 & 38.2 \\
\hline \multirow[t]{3}{*}{ Total number of pregnancy } & 1 & 67 & 32.4 & 100 & 48.3 & 167 & 40.3 \\
\hline & $2-3$ & 69 & 33.3 & 70 & 33.8 & 139 & 33.6 \\
\hline & 4 and above & 71 & 34.3 & 37 & 17.9 & 108 & 26.1 \\
\hline \multirow[t]{3}{*}{ Full and post term pregnancy } & Post term & 12 & 5.8 & 5 & 2.4 & 17 & 4.1 \\
\hline & $1-2$ & 124 & 59.9 & 165 & 79.7 & 289 & 69.8 \\
\hline & 3 and above & 71 & 34.3 & 37 & 17.9 & 108 & 26.1 \\
\hline \multirow[t]{3}{*}{ Preterm } & None & 158 & 76.3 & 178 & 86.0 & 336 & 81.2 \\
\hline & 1 & 47 & 22.7 & 26 & 12.6 & 73 & 17.6 \\
\hline & 2 and above & 2 & 1.0 & 3 & 1.4 & 5 & 1.2 \\
\hline \multirow[t]{2}{*}{ Elective termination } & None & 184 & 88.9 & 199 & 96.1 & 383 & 92.5 \\
\hline & $1-2$ & 23 & 11.1 & 8 & 3.9 & 31 & 7.5 \\
\hline \multirow[t]{3}{*}{ Miscarriage } & None & 131 & 63.3 & 174 & 84.1 & 305 & 73.7 \\
\hline & $1-2$ & 76 & 36.7 & 31 & 15.0 & 107 & 25.8 \\
\hline & 3 and above & 0 & 0 & 2 & 1.0 & 2 & 0.5 \\
\hline \multirow[t]{3}{*}{ Still birth } & None & 164 & 79.23 & 190 & 91.8 & 354 & 85.5 \\
\hline & $1-2$ & 42 & 20.29 & 17 & 8.2 & 59 & 14.3 \\
\hline & 3 and above & 1 & 0.5 & 0 & 0 & 1 & 0.2 \\
\hline \multirow[t]{3}{*}{ Neonate/Infant/child death } & None & 178 & 86.0 & 189 & 91.3 & 367 & 88.9 \\
\hline & $1-2$ & 29 & 14.0 & 17 & 8.2 & 46 & 11.1 \\
\hline & 3 and above & 0 & 0 & 1 & 0.5 & 1 & 0.2 \\
\hline \multirow[t]{3}{*}{ Living children } & None & 7 & 3.4 & 0 & 0 & 7 & 1.7 \\
\hline & $1-2$ & 129 & 62.3 & 169 & 81.6 & 298 & 72.0 \\
\hline & 3 and above & 71 & 34.3 & 38 & 18.4 & 109 & 26.3 \\
\hline \multirow[t]{2}{*}{ Gravidity } & Primigravida & 70 & 33.8 & 100 & 48.3 & 170 & 41.1 \\
\hline & Multigravida & 137 & 66.2 & 107 & 51.7 & 244 & 58.9 \\
\hline \multirow[t]{3}{*}{ Gestational age at 1st ANC (antenatal care) visit } & No ANC visit & 34 & 16.4 & 19 & 9.2 & 53 & 12.8 \\
\hline & $1-3$ months & 27 & 13.0 & 29 & 14.0 & 56 & 13.5 \\
\hline & 4 months and above & 146 & 70.5 & 159 & 76.8 & 305 & 73.7 \\
\hline \multirow[t]{6}{*}{ Institution for ANC attended } & Public hospital & 27 & 13.0 & 23 & 11.1 & 50 & 12.1 \\
\hline & Public health center & 130 & 62.8 & 147 & 71.0 & 277 & 66.9 \\
\hline & Private hospital & 6 & 2.9 & 4 & 1.9 & 10 & 2.4 \\
\hline & Private clinic & 7 & 3.4 & 13 & 6.3 & 20 & 4.8 \\
\hline & Health post & 3 & 1.4 & 1 & 0.5 & 4 & 1.0 \\
\hline & No ANC visit & 34 & 16.4 & 19 & 9.2 & 53 & 12.8 \\
\hline
\end{tabular}

Various studies suggested that multivitamin or folic acid containing multivitamin use during/ before pregnancy reduces/protects against some CAs [60, 65-68]. Multivitamins are essential organic substances, which are required by the body for normal body metabolic functions, body building, and controlling chemical reactions, such as converting food substances into energy and living tissues, as well as for survival or living healthy. Some components of multivitamins act as antioxidant substances (i.e. protect cells from damage by free radicals), for example, vitamin "E" and "C". Moreover, some components of multivitamins are also important for body defense mechanisms, for 
Table 4 Participant's response on risk factors for congenital anomaly: Results from multivariable analysis-adjusted for substance abuse/ behavioral, parental, and environmental factors, maternal illness, iron folate/folic acid, multivitamin, and vegetable use variables, Addis Ababa and the Amhara Region, Ethiopia, 2016

\begin{tabular}{|c|c|c|c|c|c|c|c|c|c|c|}
\hline \multirow[t]{2}{*}{ Characteristics } & & \multicolumn{2}{|l|}{ Cases } & \multicolumn{2}{|l|}{ Controls } & \multirow[t]{2}{*}{ COR } & \multirow[t]{2}{*}{ AOR } & \multicolumn{2}{|c|}{$95 \% \mathrm{Cl}$} & \multirow[t]{2}{*}{$P$-value } \\
\hline & & Number & $\%$ & Number & $\%$ & & & lower & upper & \\
\hline \multirow[t]{2}{*}{ Iron folate/folic acid use } & Yes & 2 & 1 & 22 & 10.6 & 0.082 & 0.051 & 0.010 & 0.260 & $<0.001$ \\
\hline & No & 205 & 99 & 185 & 89.4 & 1Ref & & & & \\
\hline \multirow[t]{2}{*}{ Unidentified medication use } & Yes & 35 & 16.9 & 8 & 3.9 & 5.062 & 4.595 & 1.868 & 11.301 & 0.001 \\
\hline & No & 172 & 83.1 & 199 & 96.1 & 1 & & & & \\
\hline \multirow[t]{2}{*}{ Drank alcohol (daily, occasionally and 1-3times in a week) } & Yes & 49 & 23.7 & 18 & 8.7 & 3.256 & 2.394 & 1.212 & 4.726 & 0.012 \\
\hline & No & 158 & 76.3 & 189 & 91.3 & 1 & & & & \\
\hline \multirow[t]{2}{*}{ Exp. to chemical (mother) } & Yes & 13 & 6.3 & 1 & 0.5 & 13.804 & 9.964 & 1.238 & 80.193 & 0.031 \\
\hline & No & 194 & 93.7 & 206 & 99.5 & 1 & & & & \\
\hline \multirow[t]{2}{*}{ Contraceptive use } & Yes & 24 & 11.6 & 5 & 2.4 & 5.298 & 4.840 & 1.647 & 14.224 & 0.004 \\
\hline & No & 183 & 88.4 & 202 & 97.6 & 1 & & & & \\
\hline \multirow[t]{2}{*}{ Blood relationship between child parents } & Yes & 10 & 4.8 & 2 & 1 & 5.203 & 6.234 & 0.959 & 40.521 & 0.055 \\
\hline & No & 197 & 95.2 & 205 & 99 & 1 & & & & \\
\hline \multirow[t]{2}{*}{ Family history } & Yes & 9 & 4.3 & 3 & 1.4 & 3.091 & 3.397 & 0.862 & 13.393 & 0.081 \\
\hline & No & 198 & 95 & 204 & 98.6 & 1 & & & & \\
\hline \multirow[t]{2}{*}{ Vegetable Serving } & Yes & 139 & 67.1 & 164 & 79.2 & 0.536 & 0.644 & 0.392 & 1.059 & 0.083 \\
\hline & No & 68 & 32.9 & 43 & 20.8 & 1 & & & & \\
\hline \multirow[t]{2}{*}{ Maternal illness } & Yes & 24 & 11.6 & 13 & 6.3 & 1.957 & 2.025 & 0.903 & 4.54 & 0.087 \\
\hline & No & 183 & 88.4 & 194 & 93.7 & 1 & & & & \\
\hline \multirow[t]{2}{*}{ Exp. to radiation before conception (child father) } & Yes & 7 & 3.4 & 2 & 1 & 3.587 & 6.838 & 0.741 & 63.109 & 0.090 \\
\hline & No & 200 & 96.6 & 205 & 99 & 1 & & & & \\
\hline
\end{tabular}

Exp exposure, COR crude odds ratio, $A O R$ adjusted odds ratio, $\mathrm{Cl}$ confidence interval, Ref reference

instance, zinc, vitamin " $\mathrm{C}$ ", and vitamin " $\mathrm{A}$ " protect the body from diseases.

As observed in this study, in Ethiopia, health care providers might not have been providing folic acid or multivitamin containing folic acid supplementation to pregnant women until recent times. However, recently the Federal Ministry of Health recommended iron folate supplementation to all pregnant women although most such women have not been provided still. Moreover, research on folic acid supplementation and knowledge of women about folic acid use during pregnancy is limited in Ethiopia.

In this study, maternal age, ethnicity, sex of child, maternal education, and parity were not significantly associated with the occurrence of CAs. This finding is in agreement with that of a study conducted in Saudi Arabia by Salih et al., [18]. However, previous studies have shown a linkage to maternal age, (greater than 35) [14, 69], maternal education, and parity with the occurrence of CA [69].

In the present study, cigarette smoking and passive smoking were not associated with CAs although several researchers reported that smoking/passive smoking was associated with a specific types of CAs [32, 70-73]. In some societies, women in the reproductive age group smoke cigarettes. This may be due to cultural and personal habits. In addition, exposure to radiation had no statistically significant link in this study. Moreover, blood relationship, family history, and the Odds of having children with CA had no statistically significant associations in this study. To the contrary, other studies reported that a significant association occurred between blood relationship/family history and CA [18, 73-75]. This variation might be due to differences in the cultures of consanguinity marriage and genetic makeup. In addition, there were no associations between birth order, preterm, miscarriage, and CAs in the present study.

In general, the present study indicates that the characteristics of cases and controls are closer, except for a few variations, like maternal alcohol drinking and maternal illness. In addition, our findings are in line with some previous reports and at variance with others. The reason they are different from the reports of some studies may be differences in socio-demographic, geographic, study setting, methodological, and environmental characteristics.

\section{Conclusion}

The findings of this study showed that alcohol drinking, unidentified medication use, and exposure to chemicals 
had significant associations with the occurrence of CAs. Iron folate use before and during pregnancy indicated a protective effect on CAs. However, current iron folate and multivitamin supplementation to pregnant women has been inadequate and infrequent because only very few women are observed using them during pregnancy, while the majority of women in the reproductive age groups are not getting prior to conception and during early pregnancy. Therefore, we emphasize that the supplementation is required to reproductive age groups, particularly around conception and during early pregnancy.

Although the causes of CAs are unknown and not studied in Ethiopia, screening nutritional deficiencies, chronic diseases, such as anemia, diabetics, infections/diseases (i.e. viral infections and sexually transmitted diseases) and establishing preventive measures, for example, health education to the public, specifically to reproductive age women are very important. So, to understand and identify the risk factors for CAs, it is necessary to conduct further population based investigations in different parts of the country to further ascertain the presently observed risk factors in association with CAs, as well as fully explore factors, which are not associated with CAs.

\section{Abbreviations}

ANC: Antenatal care; CA: Congenital anomaly; CAs: Congenital anomalies; WHO/CDC/ICBDSR: World Health Organization/Centers for Disease Control and Prevention/International clearinghouse for Birth Defects Surveillance and Research

\section{Acknowledgements}

We would like to thank midwives, nurses, and other health professionals working at Tikur Anbesa General Specialized Hospital, Zewditu Memorial Hospital, Gandhi Memorial Hospital, St. Paul Specialized Millennium Hospital, Yekatit 12 Hospital, Desse Referral Hospital, Felege Hiwet Referral Hospital, and Gondar University Hospital for their support. We would like to appreciate and acknowledge the participants. We wish to thank the medical directors and managers of the respective hospitals for their support and permission. We would also like to thank all those who assisted us in one way or another during data collection. Lastly, we would like to acknowledge Addis Ababa University and the University of Gondar for their special support.

\section{Funding}

This study obtained fund from Addis Ababa University and the University of Gondar for data collection only. The authors declare that they have not received funds for the publication of this manuscript. The authors also declare that they have had no external source of grant/fund for both data collection and publication.

\section{Availability of data and materials}

The dataset supporting the conclusion of this study are available within the manuscript.

\section{Authors' contributions}

Conceived the idea: MT. Designed the methodology: MT, MA, WF, ED, AW. Conducted the study: MT, MA, WF, ED, AW. Interpreted data: MT, MA, WF, ED, AW. Data analysis: MT, AW. Wrote draft manuscript: MT. Wrote the final manuscript: MT, AW. Review and edit the manuscript: MT, MA, WF, ED, AW. All authors read and approved the final manuscript and agreed for submission: MT, MA, WF, ED, AW.

\section{Ethics approval and consent to participate}

The study was reviewed and approved by the College of Health Sciences Institutional Review Board, Addis Ababa University, Ref. No. 060/14, dated June 12, 2014; the National Research Ethics Review Committee, Ref. No. 3.10/ 781/07, dated October 16, 2014; HARI-ALERT Ethical Review Committee, Project Reg. No. PO58/14, dated December 23, 2014; Addis Ababa City Administration Health Bureau Ethical Clearance Committee, Ref. No. A/A/H/B/1972/ 25, dated 27/10/2014; and the Amhara National Regional State Health bureau Regional Health Research Laboratory Center Ref. No. 1-2/20/4963, dated 27/01/2007(Ethiopian Calendar). Data were collected after verbal and written agreements to participate were secured from children's mothers/caregivers.

\section{Consent for publication}

Not applicable.

\section{Competing interests}

We declared that we have no financial and nonfinancial competing interests.

\section{Publisher's Note}

Springer Nature remains neutral with regard to jurisdictional claims in published maps and institutional affiliations.

\section{Author details}

${ }^{1}$ Department of Anatomy, School of Medicine, College of Medicine and Health Sciences, the University of Gondar, Gondar, Ethiopia. ${ }^{2}$ Department of Anatomy, School of Medicine, College of Health Sciences, Addis Ababa University, Addis Ababa, Ethiopia. ${ }^{3}$ School of Dentistry, College of Health Sciences, Addis Ababa University, Addis Ababa, Ethiopia. ${ }^{4}$ School of Medicine, College of Medicine and Health Sciences, the University of Gondar, Gondar, Ethiopia. ${ }^{5}$ School of Public Health, College of Health Sciences, Addis Ababa University, Addis Ababa, Ethiopia.

Received: 7 September 2016 Accepted: 20 March 2018

Published online: 25 April 2018

\section{References}

1. Francine $\mathrm{R}$, Psascale $\mathrm{S}$, Aline $\mathrm{H}$. Congenital anomalies: prevalence and risk factors. Universal J Public Health. 2014;2(2):58-63.

2. Yamada S, Nakashima T, Hirose A, Yoneyama A, Takeda T, Takakuwa T. In: Yamada S, editor. Developmental anatomy of the human embryo - 3Dimaging and analytical techniques, the human embryo; 2012. ISBN: 978-95351-0124-6, InTech, Available from: http://www.intechopen.com/books/thehuman-embryo/developmental-anatomy-of-the-human-embryo-3dimagingand-analytical-techniques.

3. Taye M, Afework M, Fantaye W, Diro E, Worku A. Magnitude of birth defects in central and Northwest Ethiopia from 2010-2014: a descriptive retrospective study. PLoS One. 2016;11(10):e0161998. https://doi.org/10. 1371/journal.pone.0161998.

4. World Health Organization/US-Center for Disease Control and Prevention/ International Clearance House on Birth Defects Surveillance and Research. Birth defects surveillance: a manual for programme managers. Geneva: World Health Organization; 2014.

5. Ahmed AM, el Kader SA, El Hamid A, Gaafar M. Assessment of risk factors for fetal congenital anomalies among pregnant women at Cairo University hospitals. J Am Sci. 2011;7(12):899-907.

6. Mohammed AR, Mohammed SA-R, AbdulFetah AMH. Congenital anomalies among children: knowledge and attitude of Egyptian and Saudi mothers. J Biol Agric Healthc. 2013;3(20):18-29.

7. Brent RL. Environmental causes of human congenital malformations: the pediatrician's role in dealing with these complex clinical problems caused by a multiplicity of environmental and genetic factors. J Am Acad Pediatr. 2004;113(4):957-68.

8. Serra-Juhe C, Rodriguez-Santiago B, Cusco I, Vendrell T, Camats N, Toran N, Perez-Jurado LA. Contribution of rare copy number variants to isolated human malformations. PLoS One. 2012;7(10):1-8.

9. Çanaku D, Toçi E, Roshi E, Burazeri G. Prevalence and factors associated with congenital malformations in Tirana Albania during 2011-201. Mater Sociomed. 2014;26(3):158-62

10. Sun G, Xu ZM, Liang JF, Li L, Tang DX. Twelve-year prevalence of common neonatal congenital malformations in Zhejiang Province, China. World J Pediatr. 2011;7(4):331-6. 
11. Kaur A, Singh JR. Chromosomal abnormalities: genetic disease burden in India. Int J Hum Genet. 2010;10(1-3):1-14.

12. Butt F, Shahzad R, Pasha I. Pattern and outcome of congenital anomalies and maternal risk factor association. Biomedica. 2013;29:234-9.

13. Basso O, Olsen J, Christensen K. Recurrence risk of congenital anomalies-the impact of paternal, social, and environmental factors: a population-based study in Denmark. Am J Epidemiol. 1999;150(6):598-604.

14. Kishimba RS, Mpembeni R, Mghamba J. Factors associated with major structural birth defects among newborns delivered at Muhimbili National Hospital and municipal hospitals in Dar Es Salaam, Tanzania 2011-2012. Pan Afr Med J. 2015;20:153. https://doi.org/10.11604/pamj.2015.20.153.4492. Available online at: http://www.panafrican-med-journal.com/content/article/ 11620/11153/full/

15. The McGraw-Hill Company. Congenital malformations. In: Kumar $P$, Burton B, editors. Evidence base evaluation and management. USA; 2008. https:// doi.org/10.1036/0071471898.

16. Bailey LB, Berry RJ. Folic acid supplementation and the occurrence of congenital heart defects, orofacial clefts, multiple births, and miscarriage1-3. Am J Clin Nutr. 2005;81(Supp. 1):1213S-12137S.

17. Malik S, Cleves MA, Honein MA, Romitti PA, Botto LD, Yang S, et al. Maternal smoking and congenital heart defects. Pediatrics. 2008;121(4):E810-6. https://doi.org/10.1542/peds.2007-1519.

18. Salih MAM, Murshid WR, Mohamed AG, Ignacio LC, de Jesus JE, Baabbad R, HME B. Risk factors for neural tube defects in Riyadh City, Saudi Arabia: case-control study. Sudan J Paediatr. 2014;14(2):49-60.

19. Grandi DC, Maccarone MB, Luchtenberg G, Rittler YM. La obesidad materna como factor de riesgo para defectos congenitos. Rev Hosp Mat Inf Ramon Sarda. 2012;31(3):100-2.

20. Desrosiers TA, Herring AH, Shapira SK, Hooiveld M, Luben TJ, Herdt-Losavio $M L$, et al. Paternal occupation and birth defects: findings from the national birth defects prevention study. Occup Environ Med. 2013;69(8):534-42.

21. Rozendaal AM, van Essen AJ, te Meerman GJ, Bakker MK, van der Biezen JJ, Goorhuis-Brouwer SM, et al. Periconceptional folic acid associated with an increased risk of oral clefts relative to non-folate related malformations in the Northern Netherlands: a population based case-control study. Eur J Epidemiol. 2013; https://doi.org/10.1007/s10654-013-9849-0.

22. Mobasheri E, Keshtkar A, Golalipour MJ. Maternal folate and vitamin B12 status and neural tube defects in northern Iran: a case control study. Iran Pediatr. 2010;20(2):167-73.

23. World Health Organization Regional Office for South-East Asia. Workshop on birth defects surveillance. Colombo; 2012. p. 10-3.

24. Prajapati V, Kacha AR, Kakkad KM, Damor PB, Nandaniya AM. Study of congenital malformation in neonates born at tertiary care hospital. National J Community Med. 2015;6(1):30-4.

25. Central Statistical Agency [Ethiopia]. Statistical abstracts: population projection of Ethiopia for all regions at wereda levels, from 2014-2017. Addis Ababa; 2013.

26. van Gelder MMHJ, Bos JHJ, Roeleveld N, de Jon-van den Berg LTW. Drugs associated with teratogenic mechanisms. Part I: dispensing rates among pregnant women in the Netherlands, 1998-2009. Hum Reprod. 2013;0(0):1-7. https:/doi.org/10.1093/humrep/det1369. http://humrep.oxfordjournals.org/

27. van Gelder MMHJ, van Rooij IALM, Miller RK, Zielhuis GA, de Jong-van den Berg LTW, Roeleveld N. Teratogenic mechanisms of medical drugs. Hum Reprod Update. 2010;16(4):378-94. https://doi.org/10.1093/humupd/dmp052.

28. Mohammed MA, Ahmed JH, Workicho A, Aljadhey HS. Medications use among pregnant women in Ethiopia: a cross sectional study. J Appl Pharm Sci. 2013;3(04):116-23. https://doi.org/10.7324/JAPS.2013.3421. Available online at http://www.japsonline.com

29. Admasie C, Wasie B, Abeje G. Determinants of prescribed drug use among pregnant women in Bahir Dar city administration, Northwest Ethiopia: a cross sectional study. BMC Pregnancy Childbirth. 2014;14:325. http://www. biomedcentral.com/1471-2393/1414/1325

30. Abeje G, Admasie C, Wasie B. Factors associated with self-medication practice among pregnant mothers attending antenatal care at governmental health centers in Bahir Dar city administration, Northwest Ethiopia, a cross sectional study. Pan Afr Med J. 2015;20:276. https://doi.org/ 10.11604/pamj.2015.20.276.4243. Available online at: http://www.panafricanmed-journal.com/content/article/11620/11276/full

31. Kebede B, Gedif T, Getachew A. Assessment of drug use among pregnant women in Addis Ababa, Ethiopia. Pharmacoepidemiol Drug Saf. 2009:18: 462-8. https://doi.org/10.1002/pds.1732.
32. Grewal J, Carmichael SL, Ma C, Lammer EJ, Shaw GM. Maternal periconceptional smoking and alcohol consumption and risk for select congenital anomalies. Birth Defects Res A. 2008;82:519-26.

33. Zhang X, Li S, Wu S, Hao X, Guo S, Suzuki K, et al. Prevalence of birth defects and risk-factor analysis from a population-based survey in Inner Mongolia, China. BMC Pediatr. 2012;12:125. https://doi.org/10.1186/14712431-12-125. http://www.biomedcentral.com/1471-2431/1112/1125

34. O'Leary CM, Elliott EJ, Nassar N, Bower C. Exploring the potential to use data linkage for investigating the relationship between birth defects and prenatal alcohol exposure. Birth Defects Res A. 2013;97:497-504.

35. O'Leary CM, Nassar N, Kurinczuk JJ, de Klerk N, Geelhoed E, Elliott EJ, Bower C. Prenatal alcohol exposure and risk of birth defects. Pediatrics. 2010;126(4): e843-50. https://doi.org/10.1542/peds.2010-0256.

36. Yeigh T, Kean B. Drinking and congenital birth defects: alcohol awareness in the northern rivers region of new South Wales, Australia. Int Electron J Health Educ. 2005;8:153-66.

37. Assadi F. Effects of prenatal alcohol exposure on the developing kidneys. Iran J Pediatr. 2008;18(1):5-10.

38. Spagnolo A. Teratogenesis of alcohol. Ann 1st Super Sanita. 1993:29(1):89-96

39. Ministry for Children and Families Edition. Parenting children affected by fetal alcohol syndrome. A guide for daily living. Ministry for children and families edition (British Columbia). Canada: Published by the society of special needs adoptive parents in cooperation with the B.C. Ministry for Children and Families Child Protection Division; 1999.

40. de Sanctis L, Memo L, Pichini S, Tarani L, Vagnarelli F. Fetal alcohol syndrome: new perspectives for an ancient and underestimated problem. The journal of maternal-fetal \& neonatal medicine : the official journal of the European Association of Perinatal Medicine, the Federation of Asia and Oceania Perinatal Societies. Int Soc Perinat Obstet. 2011;24(Suppl 1):34-7. https://doi.org/10.3109/14767058.14762011.14607576.

41. Ornoy A, Ergaz Z. Alcohol abuse in pregnant women: effects on the fetus and newborn, mode of action and maternal treatment. Int J Environ Res Public Health. 2010;7(2):364-79. https://doi.org/10.3390/ijerph7020364.

42. Streissguth AP, Bookstein FL, Barr HM, Sampson PD, O'malley K, Young JK. Risk factors for adverse life outcomes in fetal alcohol syndrome and fetal alcohol effects. Dev Behav Pediatr. 2004;25(4):228-38.

43. Werk CM, Cui X, Tough S. Fetal alcohol spectrum disorder among aboriginal children under six years of age and living off reserve: first nations Child \& Family Caring Society of Canada. First Peoples Child Fam Rev. 2013;8(1):7-13.

44. Maier SE, West JR. Drinking patterns and alcohol-related birth defects. Alcohol Res Health. 2001;25(3):168-74

45. Anteab K, Demtsu B, Megra M. Assessment of prevalence and associated factors of alcohol use during pregnancy among the dwellers of Bahir-Dar City, Northwest Ethiopia. Int J Pharma Sci Res. 2014;5(12): 939-45. ISSN: 0975-9492

46. Central Statistical Agency [Ethiopia] and ICF International. Ethiopia demographic and health survey 2011. Addis Ababa and Calverton: Central Statistical Agency and ICF International; 2012.

47. Mitro SD, Johnson T, Zota AR. Cumulative chemical exposures during pregnancy and early development. Curr Environ Health Rep. 2015;2(4):36778. https://doi.org/10.1007/s40572-40015-40064-x.

48. Bell E, Hertz-Picciotto I, Beaumont J. A case-control study of pesticides and fetal death due to congenital anomalies. Epidemiology. 2001;12(2):148-56.

49. Araneta MRG, Schlangen KM, Edmonds LD, Destiche DA, Merz RD, Hobbs CA, et al. Prevalence of birth defects among infants of gulf war veterans in Arkansas, Arizona, California, Georgia, Hawaii, and lowa, 1989-1993. Birth Defects Res A. 2003;67:246-60.

50. Dolk H, Vrijheid M, Armstrong B, Abramsky L, Bianchi F, Garne E, et al. Risk of congenital anomalies near hazardous-waste landfill site in Europe: the EUROHAZCON study. Lancet. 1998;352:423-7.

51. Heeren GA, Tyler J, Mandeya A. Agricultural chemical exposures and birth defects in the eastern Cape Province, South Africa a case - control study. Environ Health. 2003;2:11. Available from: http://www.ehjournal.net/content/12/11/11

52. WHO fact sheet on rubella: includes key facts, definition, symptoms, congenital rubella syndrome, vaccination, WHO response; 2016. Available at: http://www.who.int/mediacentre/factsheets/fs367/en/

53. WHO Fact Sheet. The measles and rubella initiative is a global partnership committed to ensuring no child dies from measles or is born with congenital rubella syndrome, 2016. http://measlesrubellainitiative.org/ resources/advocacy-tools/2016-fact-sheet/. 
54. Centers for Disease Control and Prevention (US-CDC): Congenital syphilis CDC fact sheet. 2015. www.cdc.gov/std/syphilis/stdfact-congenita.

55. Ornoy A, Tenenbaum A. Pregnancy outcome following infections by coxsackie, echo, measles, mumps, hepatitis, polio and encephalitis viruses. Reprod Toxicol. 2006:1-12. https://doi.org/10.1016/j.reprotox.2005.1012.1007. Available at www.sciencedirect.com

56. De Santis M, De Luca C, Mappa I, Spagnuolo T, Licameli A, Straface G, Scambia GS. Syphilis infection during pregnancy: fetal risks and clinical management. Infect Dis Obstet Gynecol. 2012:1-4. https://doi.org/10.1155/2012/430585.

57. Li Z, Ren A, Liu J, Pei L, Zhang L, Guo Z, Li Z. Maternal flu or fever, medication use, and neural tube defects: a population-based case-control study in northern China. Birth Defects Res A Clin Mol Teratol. 2007;79(4): 295-300. https://doi.org/10.1002/bdra.20342.

58. Liu S, Joseph KS, Lisonkova S, Rouleau J, Van den Hof M, Sauve R, Kramer MS. Association between maternal chronic conditions and congenital heart defects: a population-based cohort study. Am Heart Assoc. 2013:1-20. https://doi.org/10.1161/CIRCULATIONAHA.1112.001054. http://circ ahajournals.org/content/early/002013/001006/001027/CIRCULATIONAHA. 001112.001054

59. Csaky-Szunyogh M, Vereczkey A, Kosa Z, Gerencser B, Czeizel AE. Risk and protective factors in the origin of conotruncal defects of heart-a population-based case-control study. Am J Med Genet A. 2013;161(10): 2444-52. https://doi.org/10.1002/ajmg.a.36118.

60. Fernandez N, Henao-Mejia J, Monterrey P, Perez J, Zarante I. Association between maternal prenatal vitamin use and congenital abnormalities of the genitourinary tract in a developing country. J Pediatr Urol. 2012;8:121-6. https://doi.org/10.1016/j.jpurol.2011.07.005

61. Chan AC, Essen PV, Scott H, Haan EA, Sage L, Scott J, Gill TK, Nguyen A-MT. Folate awareness and the prevalence of neural tube defects in South Australia, 1966-2007. MJA. 2008;189(10):566-9.

62. De Wals P, Tairou F, Allen MIV, Soo-Hong U, Lowry RB, Sibbald B, et al. Reduction in neural-tube defects after folic acid fortification in Canada. N Engl J Med. 2007;357(2):135-42. www.nejm.org

63. Björklund NK, Gordon R. A hypothesis linking low folate intake to neural tube defects due to failure of post-translation methylations of the cytoskeleton. Int J Dev Biol. 2006:50:135-41. https://doi.org/10.1387/ijdb.052102nb.

64. Bortolus R, Blom F, Filippini F, van Poppel MN, Leoncini E, de Smit DJ, et al. Prevention of congenital malformations and other adverse pregnancy outcomes with $4.0 \mathrm{mg}$ of folic acid: community-based randomized clinical trial in Italy and the Netherlands. BMC Pregnancy Childbirth. 2014;14:166 https://doi.org/10.1186/1471-2393-14-166. http://www.biomedcentral.com/ 1471-2393/1114/1166

65. Wilson R, Audibert F, Brock J, Carroll J, Cartier L, Gagnon A, et al. Preconception folic acid and multivitamin supplementation for the primary and secondary prevention of neural tube defects and other folic acidsensitive congenital anomalies. J Obstet Gynaecol Can. 2015;37(6):534-52.

66. Musumeci G, Castrogiovanni P, Trovato F, Parenti R, Szychlinska M, Imbesi R. Pregnancy, embryo-fetal development and nutrition: physiology around fetal programming. J Histol Histopathol. 2015;2(1):1. https://doi.org/10.7243/ 2055-7091X-7242-7241. http://www.hoajonline.com/journals/pdf/20557091X-7242-7241.pdf

67. Munger RG, Sauberlich HE, Corcoran C, Nepomuceno B, Daack-Hirsch S, Solon FS. Maternal vitamin B-6 and folate status and risk of oral cleft birth defects in the Philippines. Birth Defects Res A Clin Mol Teratol. 2004;70(7): 464-71. https://doi.org/10.1002/bdra.20037.

68. Shaw G, Nelson V, Carmichael S, Lammer E, Finnell R, Rosenquist T. Maternal periconceptional vitamins: interactions with selected factors and congenital anomalies? Epidemiology. 2002;13(6):625-30.

69. Nili F, Jahangir T. Risk factors for neural tube defects A study at university affiliated hospitals in Tehran. Arch Iranian Med. 2006;9(1):20-5.

70. Alverson CJ, Strickland MJ, Gilboa SM, Correa A. Maternal smoking and congenital heart defects in the Baltimore-Washington infant study. Pediatrics. 2011;127(3):e647-53. https://doi.org/10.1542/peds.2010-1399. www.pediatrics.org/cgi/doi/1510.1542/peds.2010-1399

71. Little J, Arslan MT, Mossey PA. Smoking and orofacial clefts. A United Kingdom-based case-control study. Cleft Palate Craniofac J. 2004; 41(4):383-6.

72. Hackshaw A, Rodeck C, Boniface S. Maternal smoking in pregnancy and birth defects: a systematic review based on 173687 malformed cases and 11.7 million controls. Hum Reprod Update. 2011;17(5):589-604. https://doi. org/10.1093/humupd/dmr022.
73. Honein MA, Paulozzi L, Moore CA. Family history, maternal smoking, and clubfoot: an indication of a gene-environment interaction. Am J Epidemiol. 2000;152(7):658-64.

74. Raza MZ, Sheikh A, Ahmed SS, Sajid A, Naqvi SMA. Risk factors associated with birth defects at a tertiary care center in Pakistan. Ital J Pediatr. 2012; 38(68):1-7.

75. Mosayebi Z, Movahedian AH. Pattern of congenital malformations in consanguineous versus nonconsanguineous marriages in Kashan, Islamic Republic of Iran. La Revue de Sante de la Mediterranee orientale. 2007;13(4): 868-74

\section{Submit your next manuscript to BioMed Central and we will help you at every step:}

- We accept pre-submission inquiries

- Our selector tool helps you to find the most relevant journal

- We provide round the clock customer support

- Convenient online submission

- Thorough peer review

- Inclusion in PubMed and all major indexing services

- Maximum visibility for your research

Submit your manuscript at www.biomedcentral.com/submit 